OPEN ACCESS

Edited by:

Martijn Van Griensven, Technical University of Munich,

Germany

Reviewed by:

Anca Maria Cimpean,

"Victor Babes" University of Medicine and Pharmacy Timisoara, Romania

Satyaprakash Nayak,

Pfizer Inc., USA

*Correspondence:

Peter C. Searson

searson@jhu.edu

${ }^{\dagger}$ Moriah E. Katt, Amanda L. Placone, Andrew D. Wong, and Zinnia S. Xu contributed equally.

Specialty section:

This article was submitted to Tissue

Engineering and Regenerative

Medicine,

a section of the journal

Frontiers in Bioengineering and

Biotechnology

Received: 18 December 2015 Accepted: 28 January 2016

Published: 12 February 2016

Citation:

Katt ME, Placone AL, Wong AD, $X U$ ZS and Searson PC (2016) In Vitro Tumor Models: Advantages,

Disadvantages, Variables, and

Selecting the Right Platform.

Front. Bioeng. Biotechnol. 4:12. doi: 10.3389/fbioe.2016.00012

\section{In Vitro Tumor Models: Advantages, Disadvantages, Variables, and Selecting the Right Platform}

\author{
Moriah E. Katt ${ }^{1,2 \dagger}$, Amanda L. Placone ${ }^{1,2 \dagger}$, Andrew D. Wong ${ }^{1,2 \dagger}$, Zinnia S. $\mathrm{Xu}^{1,3+}$ and \\ Peter C. Searson ${ }^{1,2,4 *}$ \\ ${ }^{1}$ Institute for Nanobiotechnology (INBT), Johns Hopkins University, Baltimore, MD, USA, ${ }^{2}$ Department of Materials \\ Science and Engineering, Johns Hopkins University, Baltimore, MD, USA, ${ }^{3}$ Department of Biomedical Engineering, \\ Johns Hopkins University, Baltimore, MD, USA, ${ }^{4}$ Sidney Kimmel Comprehensive Cancer Center, Johns Hopkins University, \\ Baltimore, MD, USA
}

In vitro tumor models have provided important tools for cancer research and serve as low-cost screening platforms for drug therapies; however, cancer recurrence remains largely unchecked due to metastasis, which is the cause of the majority of cancer-related deaths. The need for an improved understanding of the progression and treatment of cancer has pushed for increased accuracy and physiological relevance of in vitro tumor models. As a result, in vitro tumor models have concurrently increased in complexity and their output parameters further diversified, since these models have progressed beyond simple proliferation, invasion, and cytotoxicity screens and have begun recapitulating critical steps in the metastatic cascade, such as intravasation, extravasation, angiogenesis, matrix remodeling, and tumor cell dormancy. Advances in tumor cell biology, 3D cell culture, tissue engineering, biomaterials, microfabrication, and microfluidics have enabled rapid development of new in vitro tumor models that often incorporate multiple cell types, extracellular matrix materials, and spatial and temporal introduction of soluble factors. Other innovations include the incorporation of perfusable microvessels to simulate the tumor vasculature and model intravasation and extravasation. The drive toward precision medicine has increased interest in adapting in vitro tumor models for patient-specific therapies, clinical management, and assessment of metastatic potential. Here, we review the wide range of current in vitro tumor models and summarize their advantages, disadvantages, and suitability in modeling specific aspects of the metastatic cascade and drug treatment.

Keywords: tumor models, transwell assay, spheroids, metastasis, microvessel models

\section{INTRODUCTION}

In vitro and in vivo animal models are important tools in cancer research, enabling the identification of carcinogens, the development of cancer therapies, drug screening, and providing insight into the molecular mechanisms of tumor growth and metastasis. In the series of steps that comprise the metastatic process, cancer cells migrate or flow through vastly different microenvironments, including stroma, blood vessel endothelium, the vascular system, and the tissue at a secondary site (Chambers et al., 2002; Fidler, 2003; Steeg, 2006). The ability 
to successfully negotiate each of these steps is dependent on the interactions between the cancer cell and the local microenvironment (Wirtz et al., 2011). Metastasis is responsible for more than $90 \%$ of cancer-related deaths (Weigelt et al., 2005; Mehlen and Puisieux, 2006); however, many details of the steps in the metastatic cascade remain poorly understood (Wirtz et al., 2011).

A wide range of mouse models have been developed of primary and metastatic tumors, including environmentally induced models, human tumor xenografts in immunocompromised mice, and genetically engineered mice (Cekanova and Rathore, 2014; Denayer et al., 2014). While in vivo models capture the complexity of the metastatic process in a living system, visualization of the individual steps is challenging and extracting quantitative mechanistic data is usually very difficult. In contrast, in vitro models have reduced physiological relevance, capturing only limited aspects of the tumor microenvironment, but allow control of most experimental variables and permit quantitative analysis.

In vitro models of solid tumors vary in complexity and range from tumor-derived cell lines to 3D models of the tumor microenvironment (Hulkower and Herber, 2011; Wirtz et al., 2011; Infanger et al., 2013; Vidi et al., 2013). Models have been developed to provide mechanistic insight into tumor growth/ proliferation, migration, invasion, matrix remodeling, dormancy, intravasation, extravasation, angiogenesis, and drug delivery. Model variables include cell sources (patient cells, commercially available cell lines, stem cells, stromal cells, immune cells, etc.), biophysical properties (oxygen partial pressure, $\mathrm{pH}$, interstitial flow, etc.), extracellular matrix (ECM) (stiffness, architecture, etc.), and biochemical cues (chemoattractants, angiogenic factors, etc.). The complexity of the model is largely dependent on the objectives. For example, preliminary screening of anticancer drugs can be performed in cell culture. Studies of invasion and motility of tumor cells can be performed with cells embedded in an ECM. Studies of intravasation and extravasation necessitate a microenvironment that incorporates one or more perfusable microvessels.

A key component of any in vitro tumor model is a source of cancer cells. Cancer cell lines are easy to grow, allow direct comparison of experimental results, and are widely used to study molecular mechanisms of tumor cell biology (Greshock et al., 2007; Holliday and Speirs, 2011). The molecular profiles of a large number of human cancer cell lines are available in the Cancer Cell Line Encyclopedia (Barretina et al., 2012), and these profiles can be compared to the profiles of a large number of human tumors, compiled as part of the Cancer Genome Atlas Research Network (Holliday and Speirs, 2011; Cancer Genome Atlas Research Network et al., 2013; Domcke et al., 2013). Patient-derived tumorgrafts capture the heterogeneity of cells in a tumor, and in some cases, the tumor histomorphology and global gene expression profile (DeRose et al., 2011); however, engraftment into a mouse or matrix material exerts a selection pressure that changes the clonal composition (Luca et al., 2013; Aparicio et al., 2015). In addition, patient-derived samples provide limited ability for comparison of experimental results. Irrespective of the cell source, models are by definition approximations of a tumor, designed to recapitulate specific aspects of the tumor microenvironment.
Advances in tumor cell biology, 3D cell culture, tissue engineering, biomaterials, microfabrication, and microfluidics have enabled rapid development of in vitro tumor models. New models are characterized by increased complexity through the incorporation of multiple cell types (coculture), ECM materials, and spatial and temporal introduction of soluble factors. Here, we review the current state-of-the-art in in vitro tumor models. For convenience, models are broadly categorized as transwell-based, spheroid-based, hybrid platforms, and tumor-microvessel models. We summarize the advantages and disadvantages of these models, identify the components of the tumor microenvironment that can be varied, and the phenomena that can be studied (Table 1). This review serves as a guide to selection of in vitro platforms best suited to specific applications in tumor biology.

\section{TRANSWELL-BASED MODELS}

\section{Introduction}

Transwell-based assays are widely used to assess cancer cell migration and invasion (Figure 1) (Hulkower and Herber, 2011; Marshall, 2011; Kramer et al., 2013). Migration is the movement of cells from one location to another and is central to the metastatic cascade (Madsen et al., 2015). Cell migration may be random or directed by gradients in soluble factors, electric field, or matrix stiffness (Rorth, 2009; Madsen et al., 2015). Invasion refers to the migration of cells in a 3D ECM (Friedl and Alexander, 2011; Friedl et al., 2012a). The three commonly used variations of transwellbased assays are (1) migration assays, (2) invasion assays, and

\begin{tabular}{ll}
\hline TABLE 1 | In vitro tumor models. \\
\hline Model & Phenomena \\
$\begin{array}{ll}\text { Transwell-based models } \\
\text { Migration } & \text { Migration, intravasation, extravasation, drug screen } \\
\text { Invasion } & \begin{array}{l}\text { Invasion, intravasation, extravasation, matrix } \\
\text { remodeling, drug screening }\end{array} \\
\text { Transendothelial } & \text { Intravasation, drug screening } \\
\text { migration } & \\
\text { Spheroid-based models } & \text { Growth/proliferation, drug screening } \\
\text { Spheroids in media } & \text { Growth/proliferation, invasion, matrix remodeling, } \\
\text { Spheroids in gels } & \begin{array}{l}\text { angiogenesis, drug screening } \\
\text { Invasion, angiogenesis, drug screening, immune }\end{array} \\
\text { Coculture } & \text { interactions }\end{array}$
\end{tabular}

\section{Hybrid models}

Embedded ex vivo Tumor growth, invasion, matrix remodeling, drug tumor sections

3D invasion models Invasion, matrix remodeling, angiogenesis, dormancy Avascular microfluidic Migration, extravasation models

\section{Tumor-microvessel models}

Predefined ECM Invasion, intravasation, extravasation, angiogenesis, scaffold

dormancy, drug delivery

Microvessel Invasion, intravasation, extravasation, angiogenesis,

self-assembly dormancy, drug delivery

Tumor models can be broadly classified as transwell-based, spheroid-based, hybrid platforms, and tumor-microvessel models. Each model has the ability to model different processes in the progression and spread of cancer. 


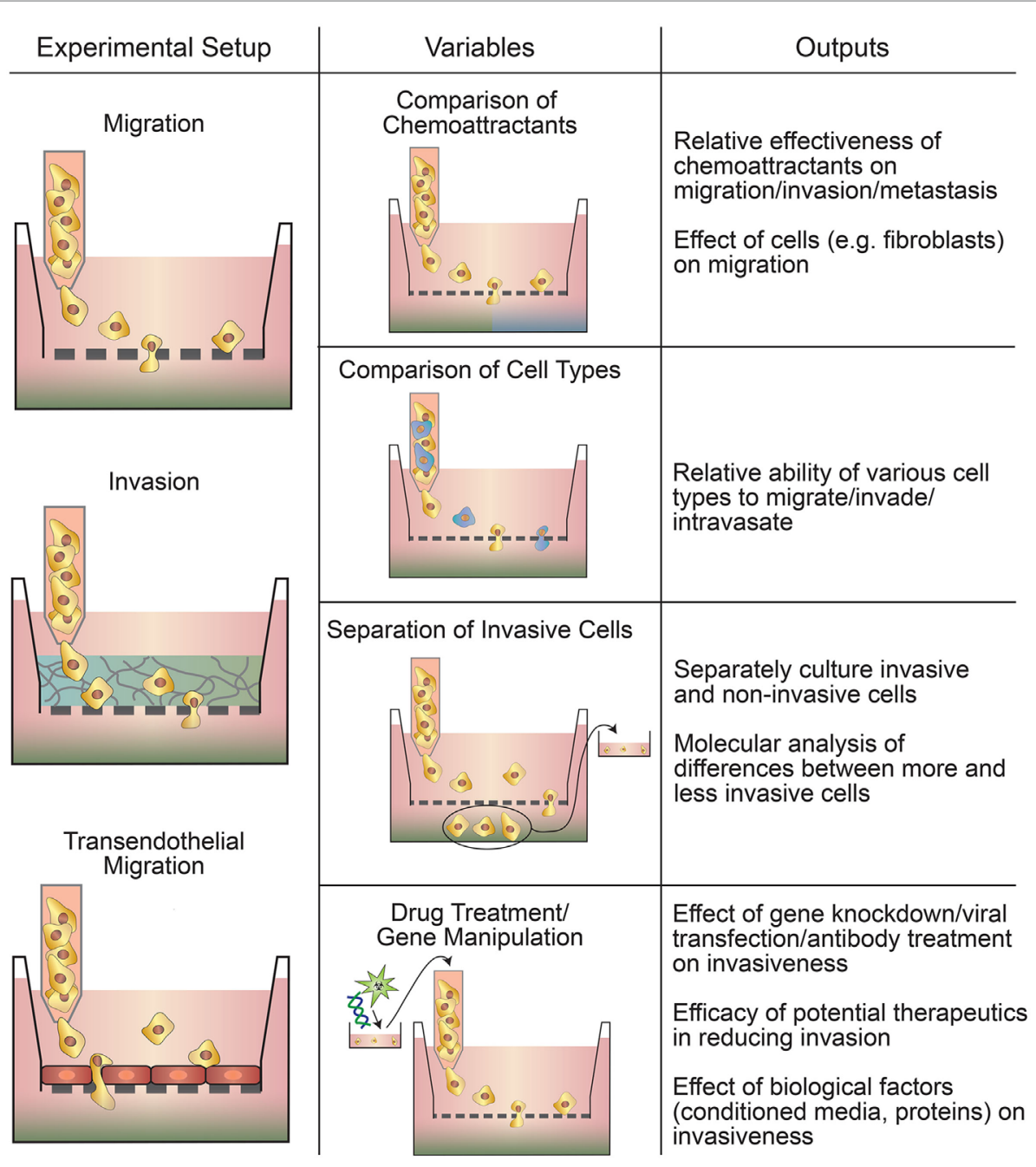

FIGURE 1 | Types of transwell-based motility assays. Migration, invasion, and transendothelial migration setups can all be used to assay multiple parameters, such as the relative invasiveness of different cells and the effect of drugs or gene manipulation on motility.

(3) transendothelial migration assays (Table 2). Migration, the simplest variation, involves seeding cancer cells directly on a porous membrane, while invasion assays involve seeding cells on a layer of ECM material on top of the porous membrane (Kramer et al., 2013). Transendothelial migration assays involve a confluent layer of endothelial cells on top of the membrane (Smith et al., 1991). Transwell-based assays are usually combined with a chemoattractant gradient, typically media with $10 \%$ FBS in the bottom chamber and media with $\leq 1 \%$ FBS in the upper chamber (Marshall, 2011; Kramer et al., 2013). Other common chemoattractants include individual growth factors (Carter and Church, 2012), ECM proteins (Kao et al., 2008), and paracrine signals from other cell types (e.g., fibroblasts) (Underwood et al., 2015).

\section{Migration Assays}

The migration assay involves seeding cancer cells on top of a porous membrane (typically with $8 \mu \mathrm{m}$ pores) and quantifying the number of cells that can migrate across the membrane toward a chemoattractant (Marshall, 2011). Cells are typically fixed after 24-72 h for imaging. Staining with either a nuclear stain or crystal violet is common for counting the migrated cells (Marshall, 2011). The bottom surface of the membrane is imaged and typically quantified by cells per imaging field. While this is a simplistic assay, the degree of migration through pores toward serum provides a high throughput in vitro model of tumor intravasation through leaky vasculature, with the pores in the membrane representing the gaps in the endothelium and serum representing the bloodstream (Pouliot et al., 2000).

\section{Invasion Assays}

Invasion assays add another level of complexity to this model. A layer of ECM is deposited on the porous membrane to model the basement membrane of the vasculature. This layer is typically Matrigel (Marshall, 2011), although collagen (Wang et al., 2010), and laminin (Rath et al., 2013) are also used. ECM layers can range in thickness up to $1 \mathrm{~mm}$ (Kramer et al., 2013). While migration 
TABLE 2 | Advantages and disadvantages of transwell-based tumor models.

\begin{tabular}{|c|c|c|c|}
\hline $\begin{array}{l}\text { Transwell } \\
\text { model }\end{array}$ & Description & Advantages & Disadvantages \\
\hline Migration & $\begin{array}{l}\text { Cancer cells pass } \\
\text { through transwell } \\
\text { membrane, } \\
\text { analogous to leaky } \\
\text { endothelium }\end{array}$ & $\begin{array}{l}\text { - Easily } \\
\text { implemented, } \\
\text { low-cost } \\
\text { assay } \\
\text { - High }\end{array}$ & $\begin{array}{l}\text { - Low } \\
\text { physiological } \\
\text { relevance } \\
\text { - Can only assay } \\
\text { single-cell }\end{array}$ \\
\hline Invasion & $\begin{array}{l}\text { Cancer cells pass } \\
\text { through a layer } \\
\text { of ECM and the } \\
\text { transwell membrane }\end{array}$ & $\begin{array}{l}\text { throughput } \\
\text { - Can be used } \\
\text { to compare } \\
\text { metastatic }\end{array}$ & $\begin{array}{l}\text { - } \text { Motility } \\
\text { invation and } \\
\text { can result in }\end{array}$ \\
\hline $\begin{array}{l}\text { Transendothelial } \\
\text { migration }\end{array}$ & $\begin{array}{l}\text { Cancer cells pass } \\
\text { through a monolayer } \\
\text { of endothelial cells to } \\
\text { assay extravasation }\end{array}$ & $\begin{array}{l}\text { potential of } \\
\text { cells }\end{array}$ & conflicting data \\
\hline
\end{tabular}

and invasion assays probe very similar properties of cells, it is worth noting that some drugs and gene manipulations have a stronger effect on the reduction of invasion than migration. For example, when transfected to overexpress TPFR-2, which inhibits MMP activity, PANC-1 pancreatic cancer cells show no reduction in migration but a 60\% reduction in invasion (Tang et al., 2010). In another study, it was found that siRNA knockdown of IMP3 resulted in decreased expression of CD-44, reduced migration by $30 \%$ while decreasing invasion by $80 \%$ (Pasiliao et al., 2015).

\section{Transendothelial Migration Assays}

Transendothelial migration assays involve plating a confluent monolayer of endothelial cells onto the porous support. This model has the additional complexity of the cell-cell junctions between endothelial cells and the ECM that they produce (Smith et al., 1991). In this configuration, transendothelial assays provide a good model of extravasation, as cancer cells must first pass through the endothelium and then the deposited basement membrane (Rahn et al., 2005). This assay can also be inverted to model intravasation by growing endothelial cells on the bottom side of the transwell membrane to confluence and seeding cancer cells in the top chamber (Pignatelli et al., 2014). These transendothelial assays are most commonly used to study brain capillary endothelium, which have tight cell-cell junctions (Lin et al., 2015), although other endothelial cell types, such as HUVECs (Pignatelli et al., 2014), are used as well.

\section{Applications of Transwell-Based Assays}

Transwell methods are used for drug screening and to study migration, intravasation, extravasation, and matrix remodeling. In most cases, transwell-based assays involve counting the number of cells that are able to translocate across the porous membrane under the experimental conditions. Many tumor cell lines exhibit a threefold to fivefold increase in the number of cells translocating across the membrane compared to non-cancerous cells (Li and Zhu, 1999), while drug and gene therapies typically reduce invasion by 30-80\% (Tang et al., 2010; Lin et al., 2015; Yang et al., 2015). Applications of transwell-based assays include (1) studies of the influence of chemoattractants on migration and invasion (Orellana et al., 2015), (2) studies of the influence of other cell types (e.g., macrophages and fibroblasts) on invasion of cancer cells (Pignatelli et al., 2014), (3) studies of the relative rates of invasion, migration, intravasation, and extravasation of different cell types ( $\mathrm{Li}$ and Zhu, 1999), (4) the isolation of invasive/non-invasive cell types for molecular analysis (Kao et al., 2008), (5) testing the influence of knockdown, transfection, and antibody treatment on invasion and migration (Gan et al., 2015), (6) assessing drug therapies in reducing invasion (Yang et al., 2015), and (7) basic studies of the role of soluble factors on invasion (Carter and Church, 2012). As an example of the application of transwell-based assays, renal cancer cells from patients with bone metastases showed a 20 -fold increase in migration toward calcium compared to cells from patients that had not metastasized (Joeckel et al., 2014). This study illustrates how a relatively straightforward in vitro assay can be used as a diagnostic tool to assess the ability of a patient's primary tumor to metastasize to a specific secondary site.

\section{SPHEROIDS}

\section{Introduction}

Spheroids are aggregates of cells grown in suspension or embedded in a 3D matrix using 3D culture methods (Figure 2) (Mueller-Klieser, 1987; Gottfried et al., 2006; Hirschhaeuser et al., 2010; LaBarbera et al., 2012; Fennema et al., 2013). Cancer cell spheroids, known as multicellular tumor spheroids (MCTS), represent avascular tumor nodules or micro-metastases (Friedrich et al., 2009). While more expensive and time consuming compared to 2D cell culture, 3D spheroids are widely used for drug screening and studies of tumor growth and proliferation, immune interactions, and for the case of spheroids embedded in a matrix, studies of invasion, matrix remodeling, and angiogenesis (Mueller-Klieser, 1987; Gottfried et al., 2006; Friedrich et al., 2007; Hirschhaeuser et al., 2010; LaBarbera et al., 2012). $3 \mathrm{D}$ spheroids recapitulate cell-cell and cell-matrix interactions between tumor cells and the microenvironment (Hirschhaeuser et al., 2010; Mehta et al., 2012; Fennema et al., 2013), as well as transport properties (Mehta et al., 2012). Larger spheroids sustain oxygen and nutrient gradients that often result in the formation of a necrotic core similar to poorly vascularized tumors (Friedrich et al., 2009). Spheroids also demonstrate proliferation gradients and zones reminiscent of tumors (Mueller-Klieser, 1987). As a result of these factors, the protein and gene expression profiles of tumor cells in spheroids are much closer to clinical and in vivo gene expression profiles than those in 2D culture (Friedrich et al., 2009; LaBarbera et al., 2012).

An important variable in MCTS is tumor size since it is correlated with cell function, as well as drug penetration and transport. In general, spheroids between 200 and $500 \mu \mathrm{m}$ are sufficiently large to develop gradients of oxygen, nutrients, and catabolites (Hirschhaeuser et al., 2010). Above a critical size of 400-600 $\mu \mathrm{m}$, spheroids develop a central secondary necrosis where the innermost cells die of apoptosis or necrosis (Gottfried et al., 2006; Friedrich et al., 2009; Hirschhaeuser et al., 2010). These larger spheroids generally have a viable cell rim that is $100-300 \mu \mathrm{m}$ thick around the necrotic core (Gottfried et al., 2006). Spheroids as small as $200 \mu \mathrm{m}$ have been used for drug testing and may be 


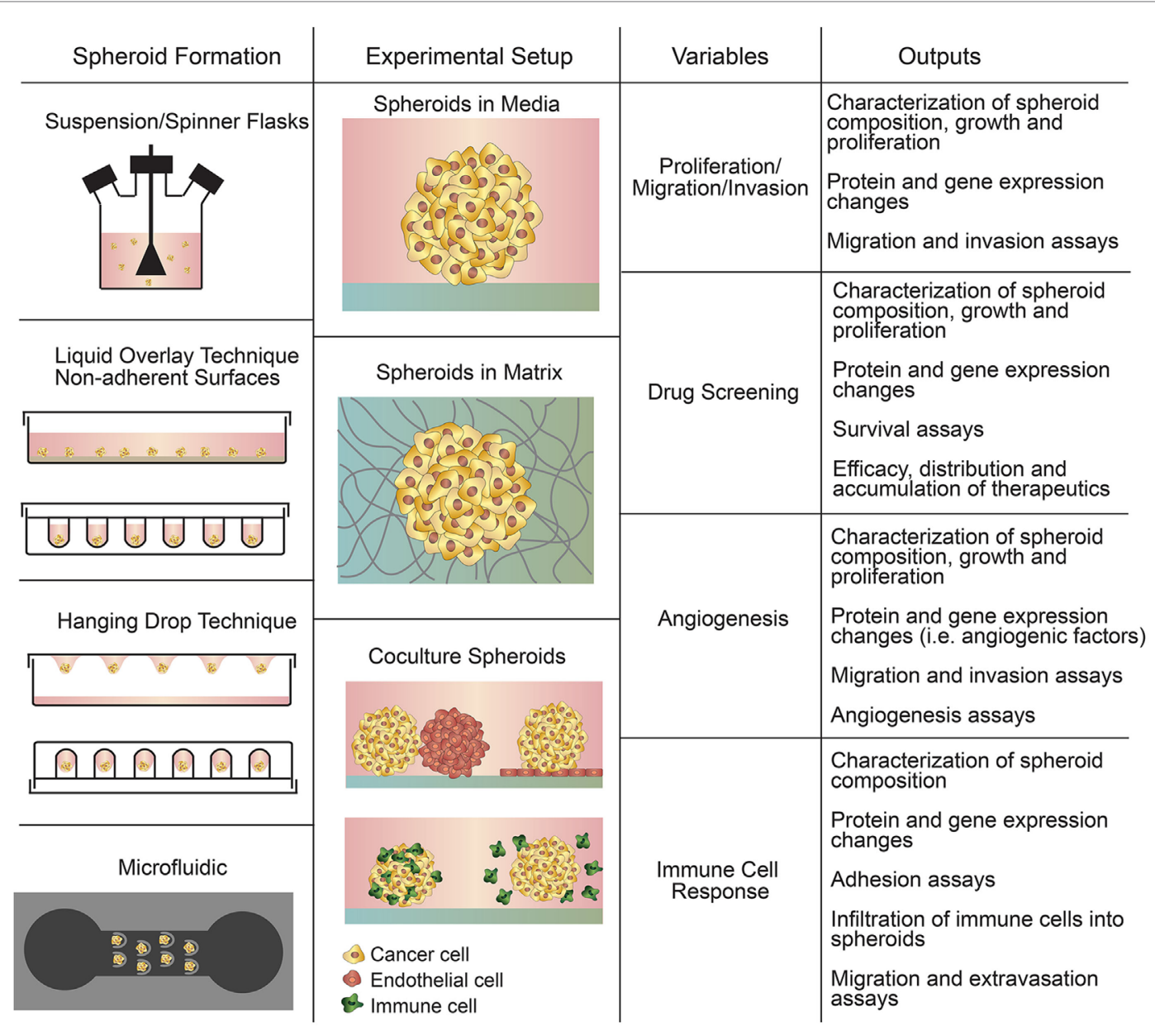

FIGURE 2 | Summary of spheroid-based assays including spheroid formation techniques, experimental setups, variables to study, and experimental outputs.

sufficient to recapitulate cell-cell and cell-matrix interactions but are not large enough to recapitulate oxygen gradients with hypoxic regions or proliferation gradients (Friedrich et al., 2009). The time to culture a $400-\mu \mathrm{m}$ spheroid (seeded at a density of 500 cells per well) is around 4 days but is dependent on cell type (Friedrich et al., 2009). For short-term culture ( $<48 \mathrm{~h}$ ), spheroids may not be as densely packed as spheroids that have been cultured for longer and may not recapitulate cell-cell and cell-matrix interactions.

\section{Spheroid Formation}

There are four general methods of spheroid formation (Figure 2), each with their distinct advantages and disadvantages (Table 3): suspension culture, non-adherent surface methods, hanging drop methods, and microfluidic methods (Mehta et al., 2012). Suspension culture methods promote spheroid formation by maintaining cells in suspension through agitation or by increasing the viscosity of the media (e.g., with the addition of carboxymethyl cellulose), thereby enabling spontaneous aggregation (Lin and Chang, 2008; Metzger et al., 2011). Suspension culture has high throughput but does not allow control of size and uniformity (Lin and Chang, 2008; Mehta et al., 2012).

Culturing cells on non-adherent surfaces prevents attachment to the substrate and promotes spheroid formation. In the liquid overlay technique (LOT), suspended cells are cultured on a non-adherent surface, such as agar, 1-1.5\% agarose, or polyHEMA (Yuhas et al., 1977; Ivascu and Kubbies, 2006; Metzger et al., 2011). Using non-adherent surfaces is straightforward but does not allow control over spheroid size and uniformity. Growth of spheroids in microarrays greatly increases throughput while allowing control of spheroid size (Hsiao et al., 2012; Mehta et al., 2012; Fennema et al., 2013). Spheroid growth can be directed using round-bottom non-adherent 96-well plates or stamped agarose microwells (Fennema et al., 2013).

The hanging drop method and techniques that employ microfluidic devices are more complex but allow better control of spheroid size and composition (Mehta et al., 2012). In the hanging drop technique, droplets of cells are suspended from the underside of an adherent tissue culture lid. Gravity drives cell aggregation into a cluster at the bottom of the drop, which then grows into a spheroid (Kelm et al., 2003). The hanging drop 
TABLE 3 | Advantages and disadvantages of tumor spheroid models.

\begin{tabular}{|c|c|c|c|}
\hline $\begin{array}{l}\text { Spheroid- } \\
\text { forming } \\
\text { method }\end{array}$ & Description & Advantages & Disadvantages \\
\hline $\begin{array}{l}\text { Cell suspension } \\
\text { culture }\end{array}$ & $\begin{array}{l}\text { Spheroids } \\
\text { are cultured } \\
\text { in suspension } \\
\text { to avoid } \\
\text { sedimentation and } \\
\text { adherence }\end{array}$ & $\begin{array}{l}\text { - Simple } \\
\text { - Mass production } \\
\text { - Long-term } \\
\text { culture }\end{array}$ & $\begin{array}{l}\text { - } \text { No individual } \\
\text { compartments } \\
\text { for spheroids } \\
\text { - Cannot control } \\
\text { uniformity (size, } \\
\text { composition) } \\
\text { - High shear } \\
\text { force }\end{array}$ \\
\hline $\begin{array}{l}\text { Non-adherent } \\
\text { surfaces }\end{array}$ & $\begin{array}{l}\text { Spheroids are } \\
\text { induced to form } \\
\text { on planar non- } \\
\text { adherent surfaces } \\
\text { or microarray wells } \\
\text { (MW) }\end{array}$ & $\begin{array}{ll}\text { - } & \text { Simple } \\
\text { - } & \text { Better efficiency } \\
& (\mathrm{MW}) \\
\text { - } & \text { High throughput } \\
& (\mathrm{MW}) \\
\text { - } & \text { Uniform spheroid } \\
& \text { size (MW) } \\
\text { - } & \text { Coculture (MW) }\end{array}$ & $\begin{array}{l}\text { - } \quad \text { Low } \\
\text { throughput } \\
\text { - } \text { Long-term } \\
\text { culture difficult }\end{array}$ \\
\hline $\begin{array}{l}\text { Hanging drop } \\
\text { technique }\end{array}$ & $\begin{array}{l}\text { Hanging droplets } \\
\text { of spheroids from } \\
\text { underside of lid }\end{array}$ & $\begin{array}{l}\text { - Control of } \\
\text { spheroid size } \\
\text { - Uniform spheroid } \\
\text { size } \\
\text { - Allows coculture } \\
\text { with defined cell } \\
\text { types }\end{array}$ & $\begin{array}{l}\text { - } \quad \text { Low } \\
\text { throughput } \\
\text { - } \quad \text { Long-term } \\
\text { culture difficult } \\
\text { - } \\
\text { Not efficient }\end{array}$ \\
\hline $\begin{array}{l}\text { Microfluidic } \\
\text { devices }\end{array}$ & $\begin{array}{l}\text { Spheroids are } \\
\text { generated within } \\
\text { microfluidic } \\
\text { channels }\end{array}$ & $\begin{array}{ll}\text { - } & \text { Control of } \\
\text { spheroid size } \\
\text { - } & \text { Control of } \\
\text { spheroid growth } \\
\text { parameters } \\
\text { - } \text { Continuous } \\
\text { perfusion } \\
\text { - Faster spheroid } \\
\text { formation }\end{array}$ & $\begin{array}{l}\text { Difficulty } \\
\text { collecting cells } \\
\text { for analysis }\end{array}$ \\
\hline
\end{tabular}

technique is relatively straightforward and allows for uniform spheroid size but is relatively low throughput, partially due to the necessity of manual media changes.

Microfluidic devices are becoming increasingly common since they allow precise control of spheroid formation (Wu et al., 2008; Mehta et al., 2012; Fu et al., 2014). Continuous perfusion under physiological conditions during spheroid formation allows for faster formation and increased size uniformity (Mehta et al., 2012). Microfluidic platforms also allow the formation, maintenance, and testing of spheroids within a single device (Wu et al., 2008).

\section{Applications of Tumor Spheroids}

Spheroids have been used in four main applications: the study of cell function (e.g., cell proliferation, migration, and invasion) in an avascular tumor microenvironment, the development of new therapies and drug screening, the study of tumor angiogenesis, and the study of tumor-immune cell interactions (Mueller-Klieser, 1987; Gottfried et al., 2006; Lin and Chang, 2008; Hirschhaeuser et al., 2010; Fennema et al., 2013).

\section{Cell Function}

Early studies of spheroids focused on recapitulating solid tumors and studying growth kinetics (size versus time), composition, and tumor cell biology (e.g., proliferation, differentiation, cell death, protein and gene expression, etc.) (Sutherland et al., 1971; Freyer and Sutherland, 1986; Durand, 1990; Friedrich et al., 2009). Studies comparing gene expression profiles of spheroids and $2 \mathrm{D}$ cultures to resected tumors revealed differences in genes associated with cell survival, proliferation, differentiation, and resistance to drug therapy and showed that spheroids more closely resembled in vivo tumors (Hirschhaeuser et al., 2010).

The ability of cells to migrate is a hallmark of the epithelial to mesenchymal transition (Gagliano et al., 2005). Cell migration assays have been developed to test therapeutics and their ability to reduce tumor cell migration and inhibit their transition to an invasive, metastatic phenotype (Rao et al., 2005; Vinci et al., 2013). Invasion studies are performed by placing spheroids on coated surfaces (i.e., vitronectin-coated) or embedding in gels (i.e., collagen type I) and measuring their invasiveness, as well as analyzing factors involved in matrix degradation and tumor invasion, such as cathepsin-B and matrix metalloproteinases (MMP) (Tamaki et al., 1997; Lakka et al., 2004; Wolf et al., 2007; Ilina et al., 2011).

\section{Drug Screening}

Cancer spheroids are widely used to assess tumor response and sensitivity to chemotherapeutics, combination therapies (e.g., chemotherapeutics and small molecule inhibitors), targeted chemotherapy, and drug delivery vehicles (L'Esperance et al., 2008; Perche et al., 2012; Mikhail et al., 2013; Sarisozen et al., 2014). Spheroids are commonly used as a high-throughput tool for negative selection of drug candidates to reduce animal testing (Friedrich et al., 2009) and for positive selection in new drug development (Hirschhaeuser et al., 2010). Drug screening typically involves spheroid formation, incubation with a drug, measurement of spheroid integrity and growth kinetics (growth delay and regrowth), and measurement of cell survival (e.g., acid phosphatase assay and colony formation assay) (Friedrich et al., 2007, 2009; Hirschhaeuser et al., 2010). The colony formation assay is used to measure the ability of a single cell to grow into a colony and is used to assess clonogenic survival (Franken et al., 2006; Hirschhaeuser et al., 2010). Overall, MCTS are more resistant to treatment than cells in 2D culture (Lin and Chang, 2008; Mehta et al., 2012; Fennema et al., 2013) and can recapitulate the drug resistance observed in solid tumors (Friedrich et al., 2009).

\section{Angiogenesis}

The potential for tumor vascularization is often assessed from the migration of endothelial cells into tumor spheroids or the formation of vascular networks within spheroids (Timmins et al., 2004). Protocols include the culture of MCTS on endothelial cell monolayers, coculture of MCTS spheroids and EC spheroids, and spheroids formed from a mixture of tumor cells and endothelial cells (Jadhav et al., 2004; Timmins et al., 2004; Ghosh et al., 2007; Upreti et al., 2011). Tumor-induced angiogenesis can increase oxygen consumption and increase expression of hypoxia-related and proangiogenic genes (Wartenberg et al., 2001). Other studies have focused on factors that induce or inhibit angiogenesis, such as MMP-9 which plays a key role in endothelial network 
organization (Jadhav et al., 2004). 3D spheroid coculture models are increasingly used in tissue engineering to modulate angiogenesis (Korff and Augustin, 1998; Korff et al., 2001; Wenger et al., 2004, 2005).

\section{Immune Cell Response}

The immune system plays an important role in the antitumor response that is primarily driven by natural killer cells, dendritic cells, and macrophages (Hickey and Kubes, 2009; Pardoll, 2012; Gajewski et al., 2013). The tumor-immune response is assessed by culturing MCTS with immune cells and observing the migration and infiltration of immune cells or by forming spheroids from tumor cells and immune cells and observing the interactions and cytotoxic effects of immune cells within tumor spheroids (Gottfried et al., 2006). Tumor cells often secrete factors that induce an immunosuppressive environment. For example, the lactic acid-rich environment surrounding tumors inhibits the cytotoxic activity of T-lymphocytes (CTLs) (Fischer et al., 2007) and reduces the migration of monocytes (Gottfried et al., 2006). Tumor spheroids are also being used to develop therapeutic strategies to stimulate an immune response by promoting infiltration and cytotoxicity of various immune cells (Durek et al., 1999; Hoffmann et al., 2009).

\section{HYBRID MODELS}

\section{Introduction}

There are several types of in vitro tumor models that cannot be classified as spheroid- or transwell-based. These include embedded ex vivo tumor sections, 3D invasion models, and avascular microfluidic models (Figure 3). These models combine the complexity of the tumor microenvironment while maintaining the relative simplicity of an in vitro model (Table 4). Embedded ex vivo tumor sections from patient biopsies can be used to select individualized chemotherapeutic regimens and fundamental studies of tumor growth and invasion (Yabushita et al., 2004). 3D invasion models reduce some of the complexities involved in the embedded biopsy samples by allowing clear visualization of specific cell interactions and interrogation of a wide range of events in the metastatic cascade. Avascular microfluidic models are the simplest in this category but still incorporate a wide range of techniques to interrogate the migration of tumor cells in a variety of geometries.

\section{Embedded Ex Vivo Tumor Sections}

The use of tumor biopsies or resected tumors sections embedded in an ECM has been employed to interrogate the tumor microenvironment in vitro (Miller et al., 1984, 1986; Dark et al., 1997; Kobayashi et al., 1997; Yamada et al., 1999; Brown et al., 2004; Xu et al., 2013). Embedded biopsies or tumor sections maintain the heterogeneity of tumor cell subpopulations, supporting tissue cells, and the tumor vasculature. While the tumor vasculature is not perfusable in these models, it is a valuable tool for characterization and study as it removes many of the in vivo complexities but maintains the cell interactions. This technique is largely used for characterization of tumor morphology, growth, and chemosensitivity (Dark et al., 1997) and has potential as a technique for screening patient-specific therapies (Xu et al., 2013).

Tumor sections are typically embedded in collagen type I as a mimic of the ECM (Nguyen-Ngoc et al., 2012), although it has been shown that the gene expression and phenotypic profiles of the cancer cells are dependent on the matrix material (Kievit et al., 2010; Nguyen-Ngoc et al., 2012). Genes associated with cell adhesion, such as the cadherins, integrins, and lectins, were significantly downregulated in experiments where disseminating cancer cells were isolated from a 3D collagen type I matrix (Nguyen-Ngoc et al., 2012). Embedded tumor sections have been used to characterize the growth and invasion of brain (Tsuchida et al., 1998; Yamada et al., 1999) and mammary tumors (Miller et al., 1984, 1986) and have been used to study drug penetration into the tumor (Netti et al., 2000; Ramanujan et al., 2002; Brown et al., 2004).

The most common use of embedded tissue sections is the culture-drug sensitivity test (CD-DST), where cells from a patient-derived tumor are cultured in collagen droplets and incubated with different anticancer drugs, and the chemosensitivity is assessed from the number of remaining viable cells. This technique has been compared to the outcomes of patients with a wide variety of tumor types (Kobayashi et al., 1997; Hanatani et al., 2000) and is currently in clinical trials as a tool in the patient-specific treatment of cancer (Yabushita et al., 2004).

\section{D Invasion Models}

While the embedded spheroid and embedded tumor section models can be used to image global growth, protrusion formation, and detachment and invasion of individual tumor cells, 3D invasion models focus specifically on invasion by seeding individual or clusters of cancer cells in an ECM material, and thus reducing some of the complexities of the tumor microenvironment. Live cell imaging is used to determine cell morphology and track the trajectories of individual cells allowing quantification of cell speed and persistence through the ECM. This approach can be used to study the role of ECM material, matrix stiffness, chemotactic gradients, and hypoxia on cell adhesion, invasion, and matrix remodeling (Liu et al., 2010; Sung et al., 2011; Koch et al., 2012; Kim et al., 2013; Shen et al., 2014; Mosadegh et al., 2015). Coculture variations of $3 \mathrm{D}$ invasion models often include a monolayer of fibroblasts, endothelial cells, or cancer cells on a matrix material with cancer cells or fibroblasts embedded in the matrix. These models can be used to study the influence of proangiogenic factors secreted by the tumor cells, as well as chemoattractants secreted by endothelial cells or fibroblasts (Krause et al., 2010; Liu et al., 2010; Shen et al., 2014; Horie et al., 2015).

\section{Avascular Microfluidic Models}

Avascular microfluidic devices are primarily used to assess cancer cell migration along small channels with respect to chemotactic gradients. Many avascular microfluidic devices study migration along small confined channels that are designed to mimic the quasi one-dimensional migration between fibers in the ECM (Fraley et al., 2010; Wirtz et al., 2011; Friedl et al., 2012b; Konstantopoulos et al., 2013). Microfluidic devices allow well-defined gradients of chemoattractants and other molecules 


\begin{tabular}{|c|c|c|}
\hline Experimental Setup & Variables & Outputs \\
\hline $\begin{array}{c}\text { Emb } \\
\text { Tu }\end{array}$ & $\begin{array}{l}\text { Extracellular matrix composition } \\
\text { Tumor source and type }\end{array}$ & $\begin{array}{l}\text { Drug screening } \\
\text { Invasion, growth, and matrix } \\
\text { remodeling potential of tumor } \\
\text { sections }\end{array}$ \\
\hline 3D Invasion & $\begin{array}{l}\text { Coculture and tumor source } \\
\text { and type } \\
\text { Microfluidic device design } \\
\text { Extracellular matrix and } \\
\text { coating compositions } \\
\text { Use of chemoattractants }\end{array}$ & $\begin{array}{l}\text { Cancer cell or stromal cell } \\
\text { invasion and matrix remodeling } \\
\text { Angiogenic sprouting } \\
\text { Mechanistic understanding of } \\
\text { dormancy }\end{array}$ \\
\hline Avascular Microfluidic & $\begin{array}{l}\text { Coculture and tumor source } \\
\text { and type } \\
\text { Microfluidic device design and } \\
\text { shear flow } \\
\text { Extracellular matrix and } \\
\text { coating composition } \\
\text { Use of chemoattractants }\end{array}$ & $\begin{array}{l}\text { Directional migration of cancer } \\
\text { cells along a gradient } \\
\text { Metastatic extravasation } \\
\text { potential and invasion through } \\
\text { extracellular matrix }\end{array}$ \\
\hline
\end{tabular}

FIGURE 3 | Hybrid models include embedded ex vivo tumor sections, 3D invasion models, and avascular microfluidic models.

TABLE 4 | Advantages and disadvantages of hybrid tumor models.

\begin{tabular}{|c|c|c|c|}
\hline Model & Description & Advantages & Disadvantages \\
\hline $\begin{array}{l}\text { Embedded } \\
\text { ex vivo tumor } \\
\text { sections }\end{array}$ & $\begin{array}{l}\text { Primary tumor } \\
\text { sections } \\
\text { or biopsies } \\
\text { embedded } \\
\text { in gel }\end{array}$ & $\begin{array}{l}\text { - } \text { Maintains tumor } \\
\text { - } \text { Paterogeneity } \\
\text { assay } \\
\text { - } \text { Mimics outgrowth } \\
\text { into surrounding } \\
\text { tissues }\end{array}$ & $\begin{array}{l}\text { - Lacks flow } \\
\text { through } \\
\text { vasculature }\end{array}$ \\
\hline $\begin{array}{l}\text { 3D invasion } \\
\text { models }\end{array}$ & $\begin{array}{l}\text { Tumor cells } \\
\text { or clusters } \\
\text { embedded in } \\
\text { a gel }\end{array}$ & $\begin{array}{l}\text { - } 3 \mathrm{D} \\
\text { microenvironment } \\
\text { - } \text { Allows real-time } \\
\text { tracking of cells } \\
\text { - } \text { Balance of } \\
\text { complexity and } \\
\text { experimental } \\
\text { control }\end{array}$ & $\begin{array}{l}\text { - Lacks } \\
\text { vasculature } \\
\text { - Lacks tumor } \\
\text { complexity }\end{array}$ \\
\hline $\begin{array}{l}\text { Avascular } \\
\text { microfluidic }\end{array}$ & $\begin{array}{l}\text { Tumor cells } \\
\text { grown in a 2D } \\
\text { microfluidic } \\
\text { device, typically } \\
\text { for the study of } \\
\text { migration }\end{array}$ & $\begin{array}{l}\text { - Simple migration } \\
\text { assay } \\
\text { - Easy to isolate } \\
\text { effect of variables } \\
\text { - } \text { Allows real-time } \\
\text { tracking of cells }\end{array}$ & $\begin{array}{l}\text { - Lacks } \\
\text { vasculature } \\
\text { - Typically lacks } \\
\text { 3D environment }\end{array}$ \\
\hline
\end{tabular}

across the channels, as well as control of oxygen partial pressure, and other stimuli (Guan et al., 2015). The channels can be coated with different adhesion proteins and/or matrix materials to modulate cell adhesion or can be filled with ECM to simulate confined migration in 3D (Chaw et al., 2007; Hou et al., 2009). As with other in vitro tumor models, multiple cell types can also be introduced (Liu et al., 2010; Ma et al., 2010; Gao et al., 2011). Experimental measurements typically involve using live cell microscopy to determine cell speed along the channels as a function of experimental conditions (channel dimensions, the presence of obstacles, coating/ECM materials, solute gradients, etc.) (Chaw et al., 2007; Hou et al., 2009). Studies in microfluidic channels have contributed to the discovery of genes required for cancer cell migration and identification of proteins, such as EGFR or CXCL12, that act as chemoattractants for cancer cells (Saadi et al., 2006; Torisawa et al., 2010).

Microfluidic models have been used to study cancer cell adhesion to endothelial monolayers as a precursor to extravasation. In these models, a monolayer of endothelial cells is formed in a microfluidic channel, and cancer cells are subsequently introduced into the channel over the endothelial monolayer at a fixed flow rate. Using live cell microscopy, the adhesion and rolling of the cancer cells can be studied as a function of shear stress with or without inhibitors or antibodies for adhesion molecules. These studies have shown that E-selectin and CXCL12 are important endothelial receptors for cancer cell adhesion (Tözeren et al., 1995; Khaldoyanidi et al., 2003; Song et al., 2009; Hsu et al., 2011).

\section{TUMOR-MICROVESSEL MODELS}

\section{Introduction}

The tumor vasculature is an important component of the tumor microenvironment providing nutrients essential for growth. The endothelial cells lining blood vessels are known to secrete factors that both promote and suppress tumor growth (Butler 
A

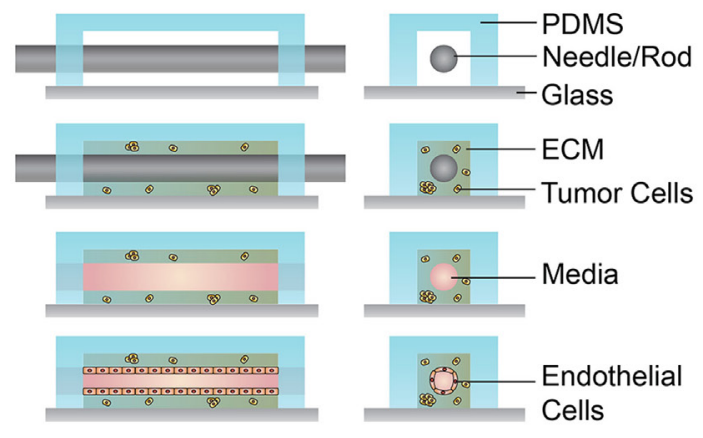

B

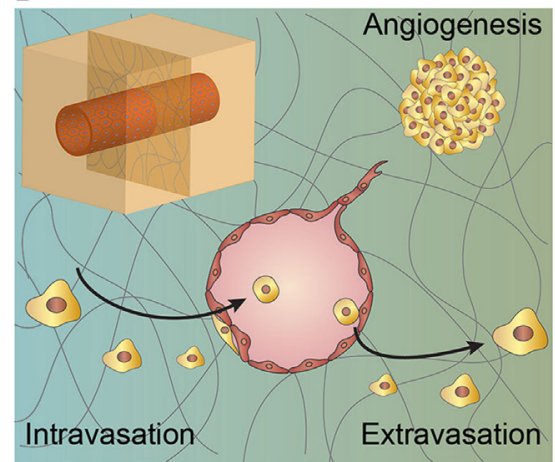

FIGURE 4 | Schematic illustration of the microvessel fabrication process and interactions between the microvessel and tumor cells in the surrounding extracellular matrix (ECM). (A) A solution form of ECM, often collagen type I or fibrin, laden with cells is introduced around the cylindrical template within the PDMS housing. After gelation/cross-linking, the template rod is removed. Endothelial cells are introduced and line the interior of the cylindrical channel. (B) Upper left inset, cylindrical channel lined with endothelial cells embedded within an ECM. The figure shows a cross-section of a cylindrical vessel interacting with tumor cells in multiple ways. Tumor cells may secrete growth factors and cytokines that promote angiogenesis from a nearby vessel. Tumor cells may invade and intravasate within the local vasculature. Tumor cells within the circulating media may extravasate by adhering to the vessel wall, transmigrating across the endothelium, and invading into the ECM.

TABLE 5 | Advantages and disadvantages of tumor-microvessel models.

\begin{tabular}{|c|c|c|c|c|}
\hline $\begin{array}{l}\text { Tumor-microvessel } \\
\text { model }\end{array}$ & Platform & Application & Advantages & Disadvantages \\
\hline $\begin{array}{l}\text { Predefined ECM } \\
\text { scaffold }\end{array}$ & $\begin{array}{l}\text { Cylindrical template/scaffold } \\
\text { Cylindrical template/scaffold } \\
\text { Cylindrical template/scaffold } \\
\text { Microfluidic-confined ECM }\end{array}$ & $\begin{array}{l}\text { Invasion and intravasation } \\
\text { Vessel paracrine signaling with } \\
\text { respect to varying shear stresses } \\
\text { Transvascular migration } \\
\text { Intravasation and extravasation }\end{array}$ & $\begin{array}{l}\text { - Well-defined vessel endothelium } \\
\text { and shear stress }\end{array}$ & $\begin{array}{l}\text { Limited vessel diameter ranges } \\
(>50 \mu \mathrm{m}) \text { and simple linear } \\
\text { geometries }\end{array}$ \\
\hline $\begin{array}{l}\text { Microvessel } \\
\text { self-assembly }\end{array}$ & $\begin{array}{l}\text { Microfluidic-confined ECM } \\
\text { Microfluidic-confined ECM } \\
\text { Free gel }\end{array}$ & $\begin{array}{l}\text { Extravasation } \\
\text { Drug toxicity screening } \\
\text { Tumor cell dormancy }\end{array}$ & $\begin{array}{l}\text { - Generates vessel sizes from } \\
\text { capillaries to small microvessels } \\
(5-50 \mu \mathrm{m}) \text { and complex networks }\end{array}$ & $\begin{array}{l}\text { Random vessel network with } \\
\text { unpredictable flow }\end{array}$ \\
\hline
\end{tabular}

et al., 2010; Ghajar et al., 2013). Furthermore, the tumor vasculature plays a critical role in several key events in the metastatic cascade, such as invasion, intravasation, and extravasation. The complex interplay between the tumor vasculature and cancer cells can be studied using in vitro tumor models that incorporate microvessels.

Microvessels used to study interactions between tumor cells and the tumor vasculature are generally fabricated by seeding endothelial cells onto predefined ECM scaffolds or self-assembled through matrix remodeling after randomly dispersing endothelial cells within an ECM (Figure 4) (Bogorad et al., 2015). Each approach has advantages and disadvantages depending on the application (Table 5).

\section{Predefined ECM Scaffold}

Cylindrical microvessels with diameters as small as $50 \mu \mathrm{m}$ can be fabricated using subtractive templating methods. These microvessels are generated by seeding endothelial cells on the internal surface of a predefined channel in an ECM, typically collagen type I or fibrin. Cells seeded on these ECM surfaces will self-assemble into a continuous monolayer and can be tested for functional properties, such as vessel permeability, expression of relevant junctional proteins, and appropriate response to vascular mediators and inflammatory cytokines (Chrobak et al., 2006). These 3D cylindrical microvessels exhibit a physiologically relevant geometry, can be maintained under shear stress, and cocultured with a variety of cell types. While it is possible to incorporate smooth muscle cells, pericytes, and lymphatic drainage within these models, the lack of such vessel characteristics is a hallmark of irregularly formed tumor vasculature (Hanahan and Weinberg, 2011; Zheng et al., 2012; Wong et al., 2013). The coculture of endothelial-lined microvessels with tumor cells permits the study of a variety of tumor-endothelial interactions, such as endothelial paracrine signaling, tumor-driven angiogenesis, intravasation, and extravasation (Figure 4) (Buchanan et al., 2014; Wong and Searson, 2014; Wang et al., 2015). The extraction of tumor cells from the surrounding ECM and analysis of their gene expression has shown that tumor cell invasiveness is mediated by the presence of microvessels and vessel shear stress (Buchanan et al., 2014). Live cell imaging of cocultured artificial microvessels with tumor cells in the surrounding ECM has recapitulated interactions thought to occur during cancer metastasis, such as invasion, tumor-driven angiogenesis, intravasation, and extravasation (Wong and Searson, 2014; Wang et al., 2015). 
Qualitative observations of invasion and intravasation suggest that one mechanism of tumor cell entry into the vasculature is mediated by tumor cell activation and division at the ECM-vessel interface resulting in mechanical disruption of the endothelial monolayer (Wong and Searson, 2014).

As a variation of the predefined scaffold model, ECM is deposited between two microfluidic channels and a monolayer of endothelial cells formed on the exposed ECM in one channel, while tumor cells are seeded in the opposing channel (Figure 5). These devices have been used to image invasion, intravasation, extravasation, and tumor-driven angiogenesis under static flow conditions and have the potential to be used as high-throughput screens for cancer invasiveness (Zervantonakis et al., 2012; Jeon et al., 2013; Lee et al., 2014).

\section{Microvessel Self-Assembly}

The aforementioned devices establish the vessel endothelium by seeding endothelial cells on predefined ECM surfaces and are thus limited to generating microvessels typically larger than $50 \mu \mathrm{m}$ in diameter due to limitations in uniform cell seeding. To achieve microvessels on the capillary scale, approximately $10-20 \mu \mathrm{m}$ in diameter, endothelial cells can be embedded within a matrix and allowed to self-assemble into a random vessel network (Figure 5). Perfusion through these vessels can be established once the networks have connected or anastomosed with nearby media ports or channels (Moya et al., 2013). Once perfusion is established, tumor cells may be circulated through the small diameter vessels, adhere to the vessel walls, and extravasate into the surrounding ECM (Chen et al., 2013). Tumor cells embedded within the surrounding ECM on the periphery of self-assembled vessel networks can be both activated or arrested in a dormant state due to interactions with the vessel endothelium (Ghajar et al., 2013).

\section{SUMMARY AND FUTURE PROSPECTS}

In vitro models allow researchers to recapitulate aspects of the tumor microenvironment using specific cell types, extracellular matrices, and soluble factors. Controlling the various components of the model enables investigation of interactions within the tumor microenvironment, as well as the response to stimuli such as chemotherapeutics. There is a wide range of tumor models, each with distinct advantages and disadvantages. Due to the inherent differences in complexity and functionality, the choice of model is usually dependent on the application. A disadvantage of the wide range of tumor models is the lack of standard protocols and the difficulty in comparing results from different models. This problem will be exacerbated by the increase in the range and complexity of models available to researchers.

Transwell-based models are widely used to study migration and invasion of cancer cells across a porous membrane, or intravasation or extravasation across an endothelial monolayer, in a simple, high-throughput $2 \mathrm{D}$ platform. The next generation of transwell models will incorporate patient-specific cells to assay migration potential as a diagnostic tool. The incorporation of target cancer cells or biopsy samples in the basolateral chamber is a high-throughput approach to combining assessment of drug transport, uptake, and efficacy in a single assay.

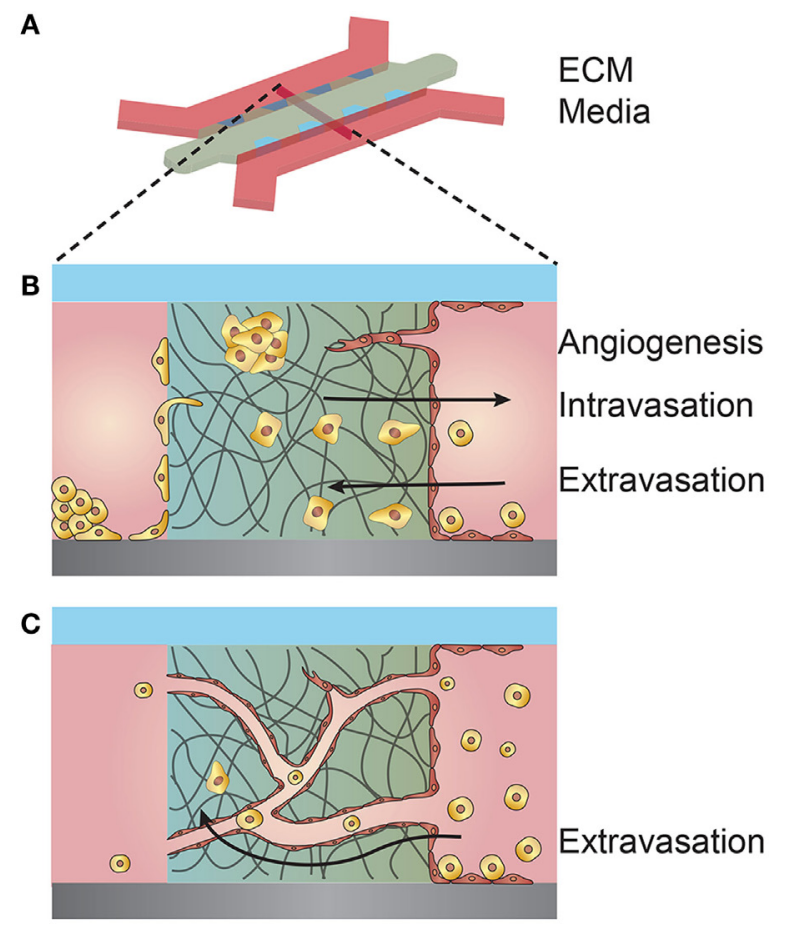

FIGURE 5 | Schematic illustration of a microfluidic device used for coculturing endothelial and tumor cells. (A) 3D schematic overview of a microfluidic device composed of an extracellular matrix (ECM) confined within PDMS posts and separating two media channels. (B) Cross-section of the coculturing device showing multiple interactions between tumor cells and a seeded endothelium. Tumor cells within the ECM may elicit an angiogenic response from the endothelium. Tumor cells introduced in the opposite media channel may invade through the ECM and intravasate across the opposing endothelium. Tumor cells introduced in the endothelial channel may extravasate by transmigrating across the endothelium and invading the ECM. (C) Endothelial cells premixed with the ECM may self-organize into a vessel network of capillaries and microvessels. The microvessels may anastomose with the separate media compartments and permit flow. Tumor cells introduced into one compartment may be circulated through the microvessel network, adhere to the vessel walls, and extravasate.

Multicellular tumor spheroids recapitulate the 3D architecture and transport phenomena of tumor tissues and can be used to investigate growth and proliferation of tumor tissues, invasion into ECM, angiogenesis, immune interactions, and drug screening. Spheroids are able to recapitulate the basic 3D structure of tumors, including multicellular structure, central necrosis, and proliferation gradients depending on tumor type. The next-generation spheroid models will likely exploit advances in embedding in ECM and coculture with other cell types, such as immune cells, to elucidate immune cell interactions. Microfluidic devices are increasingly used to form spheroids and perform rapid drug screening.

Hybrid models, such as embedded ex vivo tumor sections, are useful for investigating tumor growth, invasion, matrix remodeling, and drug screening using patient biopsies. 3D invasion models, in which single cells are embedded in a 3D ECM, are used to study invasion, matrix remodeling, angiogenesis, and dormancy. Avascular microfluidic models are used to study the 
tumor microenvironment, including migration and extravasation. Hybrid models, in particular embedded tumor sections and 3D invasion models, are well suited for patient-specific drug screening and predicting outcomes.

Tumor-microvessel models build on the complexity of avascular microfluidic models by introducing a vessel component and are particularly well suited for modeling tumor-vessel interactions over time and investigating angiogenesis, vessel-induced tumor cell dormancy, intravasation, or extravasation. Current tumor-microvessel models represent a reductive approach to studying metastasis, where at a minimum, a functional vessel lined with endothelial cells and cocultured with tumor cells is required. Sustained perfusion of the vessels improves their physiological relevance and their adaptability to live cell imaging permits the study of the mechanistic details behind intravasation and extravasation. Recent advances in quantifying gene expression within these models may be applied to understanding the biochemical interactions between vessels and tumor cells (e.g., angiocrine and tumor paracrine signaling) that determine tumor cell proliferation and dormancy and govern tumor-driven angiogenesis. Future work may improve our understanding of the tumor microenvironment and cancer progression through the manipulation of physical cues, such as shear stress and interstitial flow, introduced through the vessel and the additional coculture of other relevant cell types within the surrounding matrix (e.g., tumor-associated macrophages, neutrophils, and fibroblasts).

In summary, advances in tumor cell biology, 3D cell culture, tissue engineering, biomaterials, microfabrication, and microfluidics have enabled rapid development of in vitro tumor models.

\section{REFERENCES}

Aparicio, S., Hidalgo, M., and Kung, A. L. (2015). Examining the utility of patient-derived xenograft mouse models. Nat. Rev. Cancer 15, 311-316. doi:10.1038/nrc3944

Barretina, J., Caponigro, G., Stransky, N., Venkatesan, K., Margolin, A. A., Kim, S., et al. (2012). The cancer cell line encyclopedia enables predictive modelling of anticancer drug sensitivity. Nature 483, 603-607. doi:10.1038/nature11003

Bogorad, M. I., Destefano, J., Karlsson, J., Wong, A. D., Gerecht, S., and Searson, P. C. (2015). Review: in vitro microvessel models. Lab. Chip 15, 4242-4255. doi:10.1039/c5lc00832h

Brown, E. B., Boucher, Y., Nasser, S., and Jain, R. K. (2004). Measurement of macromolecular diffusion coefficients in human tumors. Microvasc. Res. 67, 231-236. doi:10.1016/j.mvr.2004.02.001

Buchanan, C. F., Verbridge, S. S., Vlachos, P. P., and Rylander, M. N. (2014). Flow shear stress regulates endothelial barrier function and expression of angiogenic factors in a 3D microfluidic tumor vascular model. Cell Adh. Migr. 8, 517-524. doi:10.4161/19336918.2014.970001

Butler, J. M., Kobayashi, H., and Rafii, S. (2010). Instructive role of the vascular niche in promoting tumour growth and tissue repair by angiocrine factors. Nat. Rev. Cancer 10, 138-146. doi:10.1038/nrc2791

Cancer Genome Atlas Research Network, Weinstein, J. N., Collisson, E. A., Mills, G. B., Shaw, K. R., Ozenberger, B. A., et al. (2013). The Cancer Genome Atlas Pan-Cancer analysis project. Nat. Genet. 45, 1113-1120. doi:10.1038/ ng. 2764

Carter, J. C., and Church, F. C. (2012). Mature breast adipocytes promote breast cancer cell motility. Exp. Mol. Pathol. 92, 312-317. doi:10.1016/j. yexmp.2012.03.005

Cekanova, M., and Rathore, K. (2014). Animal models and therapeutic molecular targets of cancer: utility and limitations. Drug Des. Dev. Ther. 8, 1911-1921. doi:10.2147/DDDT.S49584
Variations of traditional models are characterized by increased complexity through the incorporation of multiple cell types (coculture), ECM materials, and spatial and temporal introduction of soluble factors. Other innovations include incorporation of vessels to introduce tumor vasculature, since these leaky tumor vessels tend to influence cancer progression and drug transport. The development of 3D tumor culture systems is bridging the gap between in vitro and in vivo methods for drug screening as in vitro $3 \mathrm{D}$ models continue to develop to be better indicators of in vivo drug efficacy.

The drive toward precision medicine has resulted in increased interest in adapting in vitro tumor models for patient-specific therapies, clinical management, and assessment of metastatic potential. The next generation of in vitro tumor models will include combinations of existing models and the incorporation of new technologies for specific applications. In particular, developments in the field of organogenesis in combining a source of precursor cells that self-organize into a specific tissue or organ may be exploited in new tumor models.

\section{AUTHOR CONTRIBUTIONS}

MK, AP, AW, ZX, and PS reviewed and evaluated the literature and wrote the article.

\section{ACKNOWLEDGMENTS}

The authors acknowledge support from NIH(NCIR01CA170629).

Chambers, A. F., Groom, A. C., and Macdonald, I. C. (2002). Dissemination and growth of cancer cells in metastatic sites. Nat. Rev. Cancer 2, 563-572. doi:10.1038/nrc865

Chaw, K., Manimaran, M., Tay, E., and Swaminathan, S. (2007). Multi-step microfluidic device for studying cancer metastasis. Lab. Chip 7, 1041-1047. doi:10.1039/b707399m

Chen, M. B., Whisler, J. A., Jeon, J. S., and Kamm, R. D. (2013). Mechanisms of tumor cell extravasation in an in vitro microvascular network platform. Integr. Biol. (Camb.) 5, 1262-1271. doi:10.1039/c3ib40149a

Chrobak, K. M., Potter, D. R., and Tien, J. (2006). Formation of perfused, functional microvascular tubes in vitro. Microvasc. Res. 71, 185-196. doi:10.1016/j. mvr.2006.02.005

Dark, G. G., Hill, S. A., Prise, V. E., Tozer, G. M., Pettit, G. R., and Chaplin, D. J. (1997). Combretastatin A-4, an agent that displays potent and selective toxicity toward tumor vasculature. Cancer Res. 57, 1829-1834.

Denayer, T., Stöhr, T., and Vanroy, M. (2014). Animal models in translational medicine: validation and prediction. New Horiz. Transl. Med. 2, 5-11. doi:10.1016/j. nhtm.2014.08.001

DeRose, Y. S., Wang, G., Lin, Y. C., Bernard, P. S., Buys, S. S., Ebbert, M. T., et al. (2011). Tumor grafts derived from women with breast cancer authentically reflect tumor pathology, growth, metastasis and disease outcomes. Nat. Med. 17, 1514-1520. doi:10.1038/nm.2454

Domcke, S., Sinha, R., Levine, D. A., Sander, C., and Schultz, N. (2013). Evaluating cell lines as tumour models by comparison of genomic profiles. Nat. Commun. 4:2126. doi: $10.1038 /$ ncomms 3126

Durand, R. E. (1990). Multicell spheroids as a model for cell kinetic studies. Cell Tissue Kinet. 23, 141-159.

Durek, C., Brandau, S., Ulmer, A. J., Flad, H. D., Jocham, D., and Bohle, A. (1999). Bacillus-Calmette-Guerin (BCG) and 3D tumors: an in vitro model for the study of adhesion and invasion. J. Urol. 162, 600-605. doi:10.1016/ S0022-5347(05)68633-8 
Fennema, E., Rivron, N., Rouwkema, J., Van Blitterswijk, C., and De Boer, J. (2013). Spheroid culture as a tool for creating 3D complex tissues. Trends Biotechnol. 31, 108-115. doi:10.1016/j.tibtech.2012.12.003

Fidler, I. J. (2003). The pathogenesis of cancer metastasis: the 'seed and soil' hypothesis revisited. Nat. Rev. Cancer 3, 453-458. doi:10.1038/nrc1098

Fischer, K., Hoffmann, P., Voelkl, S., Meidenbauer, N., Ammer, J., Edinger, M., et al. (2007). Inhibitory effect of tumor cell-derived lactic acid on human T cells. Blood 109, 3812-3819. doi:10.1182/blood-2006-07-035972

Fraley, S. I., Feng, Y. F., Krishnamurthy, R., Kim, D. H., Celedon, A., Longmore, G. D., et al. (2010). A distinctive role for focal adhesion proteins in three-dimensional cell motility. Nat. Cell Biol. 12, 598-U169. doi:10.1038/ncb2062

Franken, N. A., Rodermond, H. M., Stap, J., Haveman, J., and Van Bree, C. (2006). Clonogenic assay of cells in vitro. Nat. Protoc. 1, 2315-2319. doi:10.1038/ nprot.2006.339

Freyer, J. P., and Sutherland, R. M. (1986). Regulation of growth saturation and development of necrosis in EMT6/Ro multicellular spheroids by the glucose and oxygen supply. Cancer Res. 46, 3504-3512.

Friedl, P., and Alexander, S. (2011). Cancer invasion and the microenvironment: plasticity and reciprocity. Cell 147, 992-1009. doi:10.1016/j.cell.2011.11.016

Friedl, P., Locker, J., Sahai, E., and Segall, J. E. (2012a). Classifying collective cancer cell invasion. Nat. Cell Biol. 14, 777-783. doi:10.1038/ncb2548

Friedl, P., Sahai, E., Weiss, S., and Yamada, K. M. (2012b). New dimensions in cell migration. Nat. Rev. Mol. Cell. Biol. 13, 743-747. doi:10.1038/nrm3459

Friedrich, J., Eder, W., Castaneda, J., Doss, M., Huber, E., Ebner, R., et al. (2007). A reliable tool to determine cell viability in complex 3-d culture: the acid phosphatase assay. J. Biomol. Screen. 12, 925-937. doi:10.1177/1087057107306839

Friedrich, J., Seidel, C., Ebner, R., and Kunz-Schughart, L. A. (2009). Spheroidbased drug screen: considerations and practical approach. Nat. Protoc. 4, 309-324. doi:10.1038/nprot.2008.226

Fu, C. Y., Tseng, S. Y., Yang, S. M., Hsu, L., Liu, C. H., and Chang, H. Y. (2014). A microfluidic chip with a U-shaped microstructure array for multicellular spheroid formation, culturing and analysis. Biofabrication 6:015009. doi:10.1088/1758-5082/6/1/015009

Gagliano, N., Torri, C., Donetti, E., Grizzi, F., Costa, F., Bertelli, A. A., et al. (2005). Ochratoxin A-induced renal cortex fibrosis and epithelial-to-mesenchymal transition: molecular mechanisms of ochratoxin A-injury and potential effects of red wine. Mol. Med. 11, 30-38. doi:10.2119/2006-00038.Gagliano

Gajewski, T. F., Schreiber, H., and Fu, Y. X. (2013). Innate and adaptive immune cells in the tumor microenvironment. Nat. Immunol. 14, 1014-1022. doi:10.1038/ ni. 2703

Gan, Y., Tan, J., Yang, J., Zhou, Y., Dai, Y., He, L., et al. (2015). Knockdown of HMGN5 suppresses the viability and invasion of human urothelial bladder cancer 5637 cells in vitro and in vivo. Med. Oncol. 32, 1-9. doi:10.1007/ s12032-015-0594-y

Gao, Y., Majumdar, D., Jovanovic, B., Shaifer, C., Lin, P. C., Zijlstra, A., et al. (2011). A versatile valve-enabled microfluidic cell co-culture platform and demonstration of its applications to neurobiology and cancer biology. Biomed. Microdevices 13, 539-548. doi:10.1007/s10544-011-9523-9

Ghajar, C. M., Peinado, H., Mori, H., Matei, I. R., Evason, K. J., Brazier, H., et al. (2013). The perivascular niche regulates breast tumour dormancy. Nat. Cell Biol. 15, 807-817. doi:10.1038/ncb2767

Ghosh, S., Joshi, M. B., Ivanov, D., Feder-Mengus, C., Spagnoli, G. C., Martin, I., et al. (2007). Use of multicellular tumor spheroids to dissect endothelial cell-tumor cell interactions: a role for T-cadherin in tumor angiogenesis. FEBS Lett. 581, 4523-4528. doi:10.1016/j.febslet.2007.08.038

Gottfried, E., Kunz-Schughart, L. A., Andreesen, R., and Kreutz, M. (2006). Brave little world: spheroids as an in vitro model to study tumor-immune-cell interactions. Cell Cycle 5, 691-695. doi:10.4161/cc.5.7.2624

Greshock, J., Nathanson, K., Martin, A. M., Zhang, L., Coukos, G., Weber, B. L., et al. (2007). Cancer cell lines as genetic models of their parent histology: analyses based on array comparative genomic hybridization. Cancer Res. 67, 3594-3600. doi:10.1158/0008-5472.CAN-06-3674

Guan, P.-P., Yu, X., Guo, J.-J., Wang, Y., Wang, T., Li, J.-Y., et al. (2015). By activating matrix metalloproteinase-7, shear stress promotes chondrosarcoma cell motility, invasion and lung colonization. Oncotarget 6, 9140-9159. doi:10.18632/ oncotarget.3274

Hanahan, D., and Weinberg, R. A. (2011). Hallmarks of cancer: the next generation. Cell 144, 646-674. doi:10.1016/j.cell.2011.02.013
Hanatani, Y., Kobayashi, H., Kodaira, S., Takami, H., Asagoe, T., and Kaneshiro, E. (2000). An in vitro chemosensitivity test for gastric cancer using collagen gel droplet embedded culture. Oncol. Rep. 7, 1027-1060. doi:10.3892/or.7.5.1027

Hickey, M. J., and Kubes, P. (2009). Intravascular immunity: the host-pathogen encounter in blood vessels. Nat. Rev. Immunol. 9, 364-375. doi:10.1038/nri2532

Hirschhaeuser, F., Menne, H., Dittfeld, C., West, J., Mueller-Klieser, W., and KunzSchughart, L. A. (2010). Multicellular tumor spheroids: an underestimated tool is catching up again. J. Biotechnol. 148, 3-15. doi:10.1016/j.jbiotec.2010.01.012

Hoffmann, T. K., Schirlau, K., Sonkoly, E., Brandau, S., Lang, S., Pivarcsi, A., et al. (2009). A novel mechanism for anti-EGFR antibody action involves chemokine-mediated leukocyte infiltration. Int. J. Cancer 124, 2589-2596. doi:10.1002/ ijc. 24269

Holliday, D. L., and Speirs, V. (2011). Choosing the right cell line for breast cancer research. Breast Cancer Res. 13:215. doi:10.1186/bcr2889

Horie, M., Saito, A., Yamaguchi, Y., Ohshima, M., and Nagase, T. (2015). Threedimensional co-culture model for tumor-stromal interaction. J. Vis. Exp. e52469-e52469. doi:10.3791/52469

Hou, H. W., Li, Q., Lee, G., Kumar, A., Ong, C., and Lim, C. T. (2009). Deformability study of breast cancer cells using microfluidics. Biomed. Microdevices 11, 557-564. doi:10.1007/s10544-008-9262-8

Hsiao, A. Y., Tung, Y. C., Kuo, C. H., Mosadegh, B., Bedenis, R., Pienta, K. J., et al. (2012). Micro-ring structures stabilize microdroplets to enable long term spheroid culture in 384 hanging drop array plates. Biomed. Microdevices 14, 313-323. doi:10.1007/s10544-011-9608-5

Hsu, J.-W., Yasmin-Karim, S., King, M. R., Wojciechowski, J. C., Mickelsen, D., Blair, M. L., et al. (2011). Suppression of prostate cancer cell rolling and adhesion to endothelium by $1 \alpha, 25$-dihydroxyvitamin D 3. Am. J. Pathol. 178, 872-880. doi:10.1016/j.ajpath.2010.10.036

Hulkower, K. I., and Herber, R. L. (2011). Cell migration and invasion assays as tools for drug discovery. Pharmaceutics 3, 107-124. doi:10.3390/ pharmaceutics 3010107

Ilina, O., Bakker, G. J., Vasaturo, A., Hofmann, R. M., and Friedl, P. (2011). Two-photon laser-generated microtracks in 3D collagen lattices: principles of MMP-dependent and -independent collective cancer cell invasion. Phys. Biol 8:015010. doi:10.1088/1478-3975/8/1/015010

Infanger, D. W., Cho, Y., Lopez, B. S., Mohanan, S., Liu, S. C., Gursel, D., et al. (2013). Glioblastoma stem cells are regulated by interleukin-8 signaling in a tumoral perivascular niche. Cancer Res. 73, 7079-7089. doi:10.1158/0008-5472. CAN-13-1355

Ivascu, A., and Kubbies, M. (2006). Rapid generation of single-tumor spheroids for high-throughput cell function and toxicity analysis. J. Biomol. Screen. 11, 922-932. doi:10.1177/1087057106292763

Jadhav, U., Chigurupati, S., Lakka, S. S., and Mohanam, S. (2004). Inhibition of matrix metalloproteinase- 9 reduces in vitro invasion and angiogenesis in human microvascular endothelial cells. Int. J. Oncol. 25, 1407-1414 doi:10.3892/ijo.25.5.1407

Jeon, J. S., Zervantonakis, I. K., Chung, S., Kamm, R. D., and Charest, J. L. (2013). In vitro model of tumor cell extravasation. PLoS ONE 8:e56910. doi:10.1371/ journal.pone.0056910

Joeckel, E., Haber, T., Prawitt, D., Junker, K., Hampel, C., Thüroff, J. W., et al. (2014). High calcium concentration in bones promotes bone metastasis in renal cell carcinomas expressing calcium-sensing receptor. Mol. Cancer 13:42. doi:10.1186/1476-4598-13-42

Kao, W.-T., Lin, C.-Y., Lee, L.-T., Lee, P.-P. H., Hung, C.-C., Lin, Y.-S., et al. (2008). Investigation of MMP-2 and-9 in a highly invasive A431 tumor cell sub-line selected from a Boyden chamber assay. Anticancer Res. 28, 2109-2120.

Kelm, J. M., Timmins, N. E., Brown, C. J., Fussenegger, M., and Nielsen, L. K. (2003). Method for generation of homogeneous multicellular tumor spheroids applicable to a wide variety of cell types. Biotechnol. Bioeng. 83, 173-180. doi:10.1002/bit.10655

Khaldoyanidi, S. K., Glinsky, V. V., Sikora, L., Glinskii, A. B., Mossine, V. V., Quinn, T. P., et al. (2003). MDA-MB-435 human breast carcinoma cell homo-and heterotypic adhesion under flow conditions is mediated in part by ThomsenFriedenreich antigen-galectin-3 interactions. J. Biol. Chem. 278, 4127-4134. doi:10.1074/jbc.M209590200

Kievit, F. M., Florczyk, S. J., Leung, M. C., Veiseh, O., Park, J. O., Disis, M. L., et al. (2010). Chitosan-alginate 3D scaffolds as a mimic of the glioma tumor microenvironment. Biomaterials 31, 5903-5910. doi:10.1016/j. biomaterials.2010.03.062 
Kim, B. J., Hannanta-Anan, P., Chau, M., Kim, Y. S., Swartz, M. A., and Wu, M. (2013). Cooperative roles of SDF-1alpha and EGF gradients on tumor cell migration revealed by a robust 3D microfluidic model. PLoS ONE 8:e68422. doi:10.1371/journal.pone.0068422

Kobayashi, H., Tanisaka, K., Kodama, K., Higashiyama, M., Nakagawa, H., Miyake, M., et al. (1997). An in vitro chemosensitivity test for solid human tumors using collagen gel droplet embedded cultures. Int. J. Oncol. 11, 449-455.

Koch, T.M., Münster, S., Bonakdar, N., Butler, J. P., and Fabry, B. (2012). 3D traction forces in cancer cell invasion. PLoS ONE 7:e33476. doi:10.1371/journal.pone.0033476

Konstantopoulos, K., Wu, P. H., and Wirtz, D. (2013). Dimensional control of cancer cell migration. Biophys. J. 104, 279-280. doi:10.1016/j.bpj.2012.12.016

Korff, T., and Augustin, H. G. (1998). Integration of endothelial cells in multicellular spheroids prevents apoptosis and induces differentiation. J. Cell Biol. 143, 1341-1352. doi:10.1083/jcb.143.5.1341

Korff, T., Kimmina, S., Martiny-Baron, G., and Augustin, H. G. (2001). Blood vessel maturation in a 3-dimensional spheroidal coculture model: direct contact with smooth muscle cells regulates endothelial cell quiescence and abrogates VEGF responsiveness. FASEB J. 15, 447-457. doi:10.1096/f.00-0139com

Kramer, N., Walzl, A., Unger, C., Rosner, M., Krupitza, G., Hengstschläger, M., et al. (2013). In vitro cell migration and invasion assays. Mutat. Res. 752, 10-24. doi:10.1016/j.mrrev.2012.08.001

Krause, S., Maffini, M. V., Soto, A. M., and Sonnenschein, C. (2010). The microenvironment determines the breast cancer cells' phenotype: organization of MCF7 cells in 3D cultures. BMC Cancer 10:263. doi:10.1186/1471-2407-10-263

LaBarbera, D. V., Reid, B. G., and Yoo, B. H. (2012). The multicellular tumor spheroid model for high-throughput cancer drug discovery. Expert Opin. Drug Discov. 7, 819-830. doi:10.1517/17460441.2012.708334

Lakka, S. S., Gondi, C. S., Yanamandra, N., Olivero, W. C., Dinh, D. H., Gujrati, M., et al. (2004). Inhibition of cathepsin B and MMP-9 gene expression in glioblastoma cell line via RNA interference reduces tumor cell invasion, tumor growth and angiogenesis. Oncogene 23, 4681-4689. doi:10.1038/sj.onc. 1207616

Lee, H., Park, W., Ryu, H., and Jeon, N. L. (2014). A microfluidic platform for quantitative analysis of cancer angiogenesis and intravasation. Biomicrofluidics 8:054102. doi:10.1063/1.4894595

L'Esperance, S., Bachvarova, M., Tetu, B., Mes-Masson, A. M., and Bachvarov, D. (2008). Global gene expression analysis of early response to chemotherapy treatment in ovarian cancer spheroids. BMC Genomics 9:99. doi:10.1186/1471-2164-9-99

Li, Y.-H., and Zhu, C. (1999). A modified Boyden chamber assay for tumor cell transendothelial migration in vitro. Clin. Exp. Metastasis 17, 423-429. doi:10 .1023/A:1006614232388

Lin, H. H., Chiang, M. T., Chang, P. C., and Chau, L. Y. (2015). Myeloid heme oxygenase-1 promotes metastatic tumor colonization in mice. Cancer Sci. 106, 299-306. doi:10.1111/cas.12604

Lin, R. Z., and Chang, H. Y. (2008). Recent advances in three-dimensional multicellular spheroid culture for biomedical research. Biotechnol. J. 3, 1172-1184. doi:10.1002/biot.200700228

Liu, W., Li, L., Wang, X., Ren, L., Wang, X., Wang, J., et al. (2010). An integrated microfluidic system for studying cell-microenvironmental interactions versatilely and dynamically. Lab. Chip 10, 1717-1724. doi:10.1039/c001049a

Luca, A. C., Mersch, S., Deenen, R., Schmidt, S., Messner, I., Schafer, K. L., et al. (2013). Impact of the 3D microenvironment on phenotype, gene expression, and EGFR inhibition of colorectal cancer cell lines. PLoS ONE 8:e59689. doi:10.1371/journal.pone.0059689

Ma, H., Liu, T., Qin, J., and Lin, B. (2010). Characterization of the interaction between fibroblasts and tumor cells on a microfluidic co-culture device. Electrophoresis 31, 1599-1605. doi:10.1002/elps.200900776

Madsen, C. D., Hooper, S., Tozluoglu, M., Bruckbauer, A., Fletcher, G., Erler, J. T., et al. (2015). STRIPAK components determine mode of cancer cell migration and metastasis. Nat. Cell Biol. 17, 68-80. doi:10.1038/ncb3083

Marshall, J. (2011). “Transwell ${ }^{\circledR}$ invasion assays," in Cell Migration, eds C. M. Wells, and M. Parsons (London: Springer), 97-110.

Mehlen, P., and Puisieux, A. (2006). Metastasis: a question of life or death. Nat. Rev. Cancer 6, 449-458. doi:10.1038/nrc1886

Mehta, G., Hsiao, A. Y., Ingram, M., Luker, G. D., and Takayama, S. (2012). Opportunities and challenges for use of tumor spheroids as models to test drug delivery and efficacy. J. Control Release 164, 192-204. doi:10.1016/j. jconrel.2012.04.045
Metzger, W., Sossong, D., Bachle, A., Putz, N., Wennemuth, G., Pohlemann, T., et al. (2011). The liquid overlay technique is the key to formation of co-culture spheroids consisting of primary osteoblasts, fibroblasts and endothelial cells. Cytotherapy 13, 1000-1012. doi:10.3109/14653249.2011.583233

Mikhail, A. S., Eetezadi, S., and Allen, C. (2013). Multicellular tumor spheroids for evaluation of cytotoxicity and tumor growth inhibitory effects of nanomedicines in vitro: a comparison of docetaxel-loaded block copolymer micelles and Taxotere(R). PLoS ONE 8:e62630. doi:10.1371/journal.pone.0062630

Miller, B. E., McInerney, D., Jackson, D., and Miller, F. R. (1986). Metabolic cooperation between mouse mammary tumor subpopulations in three-dimensional collagen gel cultures. Cancer Res. 46, 89-93.

Miller, B. E., Miller, F. R., and Heppner, G. H. (1984). Assessing tumor drug sensitivity by a new in vitro assay which preserves tumor heterogeneity and subpopulation interactions. J. Cell. Physiol. 121, 105-116. doi:10.1002/jcp.1041210413

Mosadegh, B., Lockett, M. R., Minn, K. T., Simon, K. A., Gilbert, K., Hillier, S., et al. (2015). A paper-based invasion assay: assessing chemotaxis of cancer cells in gradients of oxygen. Biomaterials 52, 262-271. doi:10.1016/j. biomaterials.2015.02.012

Moya, M., Tran, D., and George, S. C. (2013). An integrated in vitro model of perfused tumor and cardiac tissue. Stem Cell Res. Ther. 4(Suppl. 1):S15. doi:10.1186/scrt376

Mueller-Klieser, W. (1987). Multicellular spheroids. A review on cellular aggregates in cancer research. J. Cancer Res. Clin. Oncol. 113, 101-122. doi:10.1007/BF00391431

Netti, P. A., Berk, D. A., Swartz, M. A., Grodzinsky, A. J., and Jain, R. K. (2000). Role of extracellular matrix assembly in interstitial transport in solid tumors. Cancer Res. 60, 2497-2503.

Nguyen-Ngoc, K.-V., Cheung, K. J., Brenot, A., Shamir, E. R., Gray, R. S., Hines, W. C., et al. (2012). ECM microenvironment regulates collective migration and local dissemination in normal and malignant mammary epithelium. Proc. Natl. Acad. Sci. U.S.A. 109, E2595-E2604. doi:10.1073/pnas.1212834109

Orellana, R., Kato, S., Erices, R., Bravo, M. L., Gonzalez, P., Oliva, B., et al. (2015). Platelets enhance tissue factor protein and metastasis initiating cell markers, and act as chemoattractants increasing the migration of ovarian cancer cells. BMC Cancer 15:290. doi:10.1186/s12885-015-1304-Z

Pardoll, D. M. (2012). The blockade of immune checkpoints in cancer immunotherapy. Nat. Rev. Cancer 12, 252-264. doi:10.1038/nrc3239

Pasiliao, C. C., Chang, C.-W. A., Sutherland, B. W., Valdez, S. M., Schaeffer, D., Yapp, D. T., et al. (2015). The involvement of insulin-like growth factor 2 binding protein 3 (IMP3) in pancreatic cancer cell migration, invasion, and adhesion. BMC Cancer 15:266. doi:10.1186/s12885-015-1251-8

Perche, F., Patel, N. R., and Torchilin, V. P. (2012). Accumulation and toxicity of antibody-targeted doxorubicin-loaded PEG-PE micelles in ovarian cancer cell spheroid model. J. Control Release 164, 95-102. doi:10.1016/j. jconrel.2012.09.003

Pignatelli, J., Goswami, S., Jones, J. G., Rohan, T. E., Pieri, E., Chen, X., et al. (2014). Invasive breast carcinoma cells from patients exhibit MenaINV- and macrophage-dependent transendothelial migration. Sci. Signal. 7:ra112. doi:10.1126/ scisignal.2005329

Pouliot, N., Pearson, H. B., and Burrows, A. (2000). Investigating Metastasis Using In Vitro Platforms. Austin (TX): Landes Bioscience.

Rahn, J. J., Chow, J. W., Horne, G. J., Mah, B. K., Emerman, J. T., Hoffman, P., et al. (2005). MUC1 mediates transendothelial migration in vitro by ligating endothelial cell ICAM-1. Clin. Exp. Metastasis 22, 475-483. doi:10.1007/ s10585-005-3098-x

Ramanujan, S., Pluen, A., McKee, T. D., Brown, E. B., Boucher, Y., and Jain, R. K. (2002). Diffusion and convection in collagen gels: implications for transport in the tumor interstitium. Biophys. J. 83, 1650-1660. doi:10.1016/ S0006-3495(02)73933-7

Rao, J. S., Gondi, C., Chetty, C., Chittivelu, S., Joseph, P. A., and Lakka, S. S. (2005). Inhibition of invasion, angiogenesis, tumor growth, and metastasis by adenovirus-mediated transfer of antisense UPAR and MMP-9 in non-small cell lung cancer cells. Mol. Cancer Ther. 4, 1399-1408. doi:10.1158/1535-7163. MCT-05-0082

Rath, B. H., Fair, J. M., Jamal, M., Camphausen, K., and Tofilon, P. J. (2013). Astrocytes enhance the invasion potential of glioblastoma stem-like cells. PLoS ONE 8:e54752. doi:10.1371/journal.pone.0054752

Rorth, P. (2009). Collective cell migration. Annu. Rev. Cell Dev. Biol. 25, 407-429. doi:10.1146/annurev.cellbio.042308.113231 
Saadi, W., Wang, S.-J., Lin, F., and Jeon, N. L. (2006). A parallel-gradient microfluidic chamber for quantitative analysis of breast cancer cell chemotaxis. Biomed. Microdevices 8, 109-118. doi:10.1007/s10544-006-7706-6

Sarisozen, C., Abouzeid, A. H., and Torchilin, V. P. (2014). The effect of co-delivery of paclitaxel and curcumin by transferrin-targeted PEG-PE-based mixed micelles on resistant ovarian cancer in 3-D spheroids and in vivo tumors. Eur. J. Pharm. Biopharm. 88, 539-550. doi:10.1016/j.ejpb.2014.07.001

Shen, Y.-I., Abaci, H. E., Krupski, Y., Weng, L.-C., Burdick, J. A., and Gerecht, S. (2014). Hyaluronic acid hydrogel stiffness and oxygen tension affect cancer cell fate and endothelial sprouting. Biomater. Sci. 2, 655-665. doi:10.1039/c3bm60274e

Smith, W., Gamble, J., Clark-Lewis, I., and Vadas, M. (1991). Interleukin-8 induces neutrophil transendothelial migration. Immunology 72:65.

Song, J. W., Cavnar, S. P., Walker, A. C., Luker, K. E., Gupta, M., Tung, Y.-C., et al. (2009). Microfluidic endothelium for studying the intravascular adhesion of metastatic breast cancer cells. PLoS ONE 4:e5756. doi:10.1371/journal.pone.0005756

Steeg, P. S. (2006). Tumor metastasis: mechanistic insights and clinical challenges. Nat. Med. 12, 895-904. doi:10.1038/nm1469

Sung, K. E., Yang, N., Pehlke, C., Keely, P. J., Eliceiri, K. W., Friedl, A., et al. (2011). Transition to invasion in breast cancer: a microfluidic in vitro model enables examination of spatial and temporal effects. Integr. Biol. (Camb.) 3, 439-450. doi:10.1039/c0ib00063a

Sutherland, R. M., McCredie, J. A., and Inch, W. R. (1971). Growth of multicell spheroids in tissue culture as a model of nodular carcinomas. J. Natl. Cancer Inst. 46, 113-120.

Tamaki, M., McDonald, W., Amberger, V. R., Moore, E., and Del Maestro, R. F. (1997). Implantation of C6 astrocytoma spheroid into collagen type I gels: invasive, proliferative, and enzymatic characterizations. J. Neurosurg. 87, 602-609. doi:10.3171/jns.1997.87.4.0602

Tang, Z., Geng, G., Huang, Q., Xu, G., Hu, H., Chen, J., et al. (2010). Prognostic significance of tissue factor pathway inhibitor-2 in pancreatic carcinoma and its effect on tumor invasion and metastasis. Med. Oncol. 27, 867-875. doi:10.1007/ s12032-009-9298-5

Timmins, N. E., Dietmair, S., and Nielsen, L. K. (2004). Hanging-drop multicellular spheroids as a model of tumour angiogenesis. Angiogenesis 7, 97-103. doi:10.1007/s10456-004-8911-7

Torisawa, Y.-S., Mosadegh, B., Bersano-Begey, T., Steele, J. M., Luker, K. E., Luker, G. D., et al. (2010). Microfluidic platform for chemotaxis in gradients formed by CXCL12 source-sink cells. Integr. Biol. (Camb.) 2, 680-686. doi:10.1039/c0ib00041h

Tözeren, A., Kleinman, H. K., Grant, D. S., Morales, D., Mercurio, A. M., and Byers, S. W. (1995). E-selectin-mediated dynamic interactions of breast- and colon-cancer cells with endothelial-cell monolayers. Int. J. Cancer 60, 426-431. doi:10.1002/ijc.2910600326

Tsuchida, T., Yamada, A., Yoshimura, K., and Kawamoto, K. (1998). Ultrastructural characterization of central neurocytomas using collagen gel culture. Ultrastruct. Pathol. 22, 233-238. doi:10.3109/01913129809033474

Underwood, T. J., Hayden, A. L., Derouet, M., Garcia, E., Noble, F., White, M. J., et al. (2015). Cancer-associated fibroblasts predict poor outcome and promote periostin-dependent invasion in oesophageal adenocarcinoma. J. Pathol. 235, 466-477. doi:10.1002/path.4467

Upreti, M., Jamshidi-Parsian, A., Koonce, N. A., Webber, J. S., Sharma, S. K., Asea, A. A., et al. (2011). Tumor-endothelial cell three-dimensional spheroids: new aspects to enhance radiation and drug therapeutics. Transl. Oncol. 4, 365-376. doi:10.1593/tlo.11187

Vidi, P. A., Bissell, M. J., and Lelievre, S. A. (2013). Three-dimensional culture of human breast epithelial cells: the how and the why. Methods Mol. Biol. 945, 193-219. doi:10.1007/978-1-62703-125-7_13

Vinci, M., Box, C., Zimmermann, M., and Eccles, S. A. (2013). Tumor spheroid-based migration assays for evaluation of therapeutic agents. Methods Mol. Biol. 986, 253-266. doi:10.1007/978-1-62703-311-4_16

Wang, F.-Q., Ariztia, E. V., Boyd, L. R., Horton, F. R., Smicun, Y., Hetherington, J. A., et al. (2010). Lysophosphatidic acid (LPA) effects on endometrial carcinoma in vitro proliferation, invasion, and matrix metalloproteinase activity. Gynecol. Oncol. 117, 88-95. doi:10.1016/j.ygyno.2009.12.012

Wang, X. Y., Pei, Y., Xie, M., Jin, Z. H., Xiao, Y. S., Wang, Y., et al. (2015). An artificial blood vessel implanted three-dimensional microsystem for modeling transvascular migration of tumor cells. Lab. Chip 15, 1178-1187. doi:10.1039/ c4lc00973h
Wartenberg, M., Donmez, F., Ling, F. C., Acker, H., Hescheler, J., and Sauer, H. (2001). Tumor-induced angiogenesis studied in confrontation cultures of multicellular tumor spheroids and embryoid bodies grown from pluripotent embryonic stem cells. FASEB J. 15, 995-1005. doi:10.1096/ fj.00-0350com

Weigelt, B., Peterse, J. L., and van't Veer, L. J. (2005). Breast cancer metastasis: markers and models. Nat. Rev. Cancer 5, 591-602. doi:10.1038/nrc1670

Wenger, A., Kowalewski, N., Stahl, A., Mehlhorn, A. T., Schmal, H., Stark, G. B., et al. (2005). Development and characterization of a spheroidal coculture model of endothelial cells and fibroblasts for improving angiogenesis in tissue engineering. Cells Tissues Organs 181, 80-88. doi:10.1159/000091097

Wenger, A., Stahl, A., Weber, H., Finkenzeller, G., Augustin, H. G., Stark, G. B., et al. (2004). Modulation of in vitro angiogenesis in a three-dimensional spheroidal coculture model for bone tissue engineering. Tissue Eng. 10, 1536-1547. doi:10.1089/ten.2004.10.1536

Wirtz, D., Konstantopoulos, K., and Searson, P. C. (2011). The physics of cancer: the role of physical interactions and mechanical forces in metastasis. Nat. Rev. Cancer 11, 512-522. doi:10.1038/nrc3080

Wolf, K., Wu, Y. I., Liu, Y., Geiger, J., Tam, E., Overall, C., et al. (2007). Multi-step pericellular proteolysis controls the transition from individual to collective cancer cell invasion. Nat. Cell Biol. 9, 893-904. doi:10.1038/ ncb 1616

Wong, A. D., and Searson, P. C. (2014). Live-cell imaging of invasion and intravasation in an artificial microvessel platform. Cancer Res. 74, 4937-4945. doi:10.1158/0008-5472.CAN-14-1042

Wong, K. H., Truslow, J. G., Khankhel, A. H., Chan, K. L., and Tien, J. (2013). Artificial lymphatic drainage systems for vascularized microfluidic scaffolds. J. Biomed. Mater. Res. A. 101, 2181-2190. doi:10.1002/jbm.a.34524

Wu, L. Y., Di Carlo, D., and Lee, L. P. (2008). Microfluidic self-assembly of tumor spheroids for anticancer drug discovery. Biomed. Microdevices 10, 197-202. doi:10.1007/s10544-007-9125-8

Xu, Z., Gao, Y., Hao, Y., Li, E., Wang, Y., Zhang, J., et al. (2013). Application of a microfluidic chip-based 3D co-culture to test drug sensitivity for individualized treatment of lung cancer. Biomaterials 34, 4109-4117. doi:10.1016/j. biomaterials.2013.02.045

Yabushita, H., Ohnishi, M., Komiyama, M., Mori, T., Noguchi, M., Kishida, T., et al. (2004). Usefulness of collagen gel droplet embedded culture drug sensitivity testing in ovarian cancer. Oncol. Rep. 12, 307-311. doi:10.3892/ or.12.2.307

Yamada, A., Tsuchida, T., Yamanouchi, Y., and Kawamoto, K. (1999). Ultrastructural characterization of brain tumors using collagen gel culture. Neuropathology 19, 366-369. doi:10.1046/j.1440-1789.1999.00253.x

Yang, F., Hu, M., Lei, Q., Xia, Y., Zhu, Y., Song, X., et al. (2015). Nifuroxazide induces apoptosis and impairs pulmonary metastasis in breast cancer model. Cell Death Dis. 6:e1701. doi:10.1038/cddis.2015.63

Yuhas, J. M., Li, A. P., Martinez, A. O., and Ladman, A. J. (1977). A simplified method for production and growth of multicellular tumor spheroids. Cancer Res. 37, 3639-3643.

Zervantonakis, I. K., Hughes-Alford, S. K., Charest, J. L., Condeelis, J. S., Gertler, F. B., and Kamm, R. D. (2012). Three-dimensional microfluidic model for tumor cell intravasation and endothelial barrier function. Proc. Natl. Acad. Sci. U.S.A. 109, 13515-13520. doi:10.1073/pnas.1210182109

Zheng, Y., Chen, J., Craven, M., Choi, N. W., Totorica, S., Diaz-Santana, A., et al. (2012). In vitro microvessels for the study of angiogenesis and thrombosis. Proc. Natl. Acad. Sci. U.S.A. 109, 9342-9347. doi:10.1073/pnas.1201240109

Conflict of Interest Statement: The authors declare that the research was conducted in the absence of any commercial or financial relationships that could be construed as a potential conflict of interest.

Copyright (c) 2016 Katt, Placone, Wong, Xu and Searson. This is an open-access article distributed under the terms of the Creative Commons Attribution License (CC BY). The use, distribution or reproduction in other forums is permitted, provided the original author(s) or licensor are credited and that the original publication in this journal is cited, in accordance with accepted academic practice. No use, distribution or reproduction is permitted which does not comply with these terms. 